\title{
Assessment of Social Competence Perceived in Martial Arts and Tendency towards Sport Activities
}

\author{
Abdulkerim Çeviker (Corresponding author) \\ Department of Recreation, Faculty of Sports Sciences, Hitit University, Çorum, Turkey \\ Tel: 90-542-377-9906_E-mail: kerimceviker@gmail.com
}

Gamze Deryahanoğlu

Department of Recreation, Faculty of Sport Sciences, Hitit University, Çorum, Turkey

Tel: 90-534-705-6997 E-mail: gamze_dryhngl@hotmail.com

Osman Kusan

School of Physical Education and Sports, Department of Sports Management

Gümüşhane University, Gümüşhane, Turkey

Tel: 90-532-286-2110_E-mail: osmankusan@gumushane.edu.tr

Received: November 9, 2021 Accepted: December 20, 2021

Published: December 31, 2021

doi:10.5296/jei.v7i2.19167 URL: https://doi.org/10.5296/jei.v7i2.19167

\begin{abstract}
Considering that the socially perceived competence in athletes shall continue not only the tendency to the sport activities but also the mutual effects of showing more effort and participation in sport activities, our aim is to assess the perceived competence and tendency towards sport activities in martial arts athletes.

The study is composed total of 220 athletes, 92 males and 128 females, in the branches of Kickboxing, Taekwondo, and Boxing. In the research, in order to determine the "Tendency towards Sports Activities" and the "Perceive Social Competence" levels of the athletes are used. The analysis of the data is performed utilizing SPSS 22.0 package program. In group comparisons, the Mann-Whitney U Test, Kruskal-Wallis Test are used. The analysis of the data is assessed at $95 \%$ confidence interval and $\mathrm{p}<0.05$ significance level.
\end{abstract}


There are significant differences determined in perceived social competence, total score of tendency towards sports and emotion search sub dimension based on the genders of the athletes. Based on the branch variable of the athletes, in perceived social competence, general scale tendency towards sports, socializing sub dimension and emotion search sub dimension, significant differences are determined.

As a result, it is concluded that they follow up-to-date sports regularly and this increases the social competence and sports tendency of the athletes; that Kickboxing athletes, the one who started the sport on their own will and male athletes have higher social competence and sport tendencies.

Keywords: social competence perceived, tendency sport activities, kickboxing, taekwondo, boxing

\section{Introduction}

With effects seen in many activity fields, sport plays an increasingly important role in modern societies. Looking from an economic perspective, sports constitute an important part of the entertainment and service sectors. For example, the number of people participating in football in America is 16 million, in South America 45 million, in Africa 90 million, whereas in Turkey, according to the Five Year Development Plan Sports Specialization Commission (OIK) report of 2013, the ratio of participants in all sport branches as licensed to the population is $7.3 \%$ and that of active participants is 3.8\% (King, 2004; Ministry of Development, 2013; Sunay, 2019). Such participation levels affect not only football but also other branches. Ak (2017), in their study, suggested that despite there is a greater interest in Football and Volleyball in Turkey with football being at the 1st places, Taekwondo at the 2nd place, Volleyball at the 3rd place, the country has a tendency mainly towards far eastern sports. Considering that understanding the dimensions under the tendency to sport activities is valuable to event organizers and managers, the importance of revealing these dimensions is more clearly understood (Pons et al., 2006). When we look through the perspective of the athletes, each athlete may have different characteristics both physically and psychologically. Based on these causes, it can be said that there are challenges regarding the direction and management of the athletes. In this era, it is frequently seen athletes leaving sports completely due to not setting correct goals (Başer 1996; Eniseler, 2009; Balyan, 2012; Ceylan et al., 2020).

The environmental conditions to be formed should develop the competition orientation of the athletes in sports towards the desired directions and should provide for the athletes especially the positive social skills. In this regard, the sportive events where the communication with environment increases, takes an important position in forming and developing the tendency of persons in activities in sports and positive social competences (Röthig \& Grössing, 2002; Balyan, 2012). Also it is shown that the perceived social competences of the athletes have an important role in understanding the motivational and sport activity participation tendencies and behaviors of the athletes (Rottensteiner et al., 2015). Cervello et al., (2007) emphasized that the perceived social competences may have a positive effect on the success goals of the young athletes. Ntoumanis (2001) indicated that the perceived social competence of the 
athletes is seen strongly to provide participation behaviors in sport activities as organized for the athletes. It is not only that perceived social competence affecting the sports participation but it is also that the positive effect of the participation in sport activities on social qualification degrees can explain the role of sport activities in improving the general spiritual health and incentivizing the positive social skill development (Bedard et al., 2020).

Considering that socially perceived competence in athletes shall continue not only the tendency towards sport activities but also the mutual effect of giving more effort and participation to the sport activities, our goal is to assess the perceived social competence and tendency towards sport activities of the martial artists.

\section{Method}

\subsection{The Study Group}

Consider using appendices and/or a supplemental website for more detailed information. The study group consists of the athletes in Kickboxing, Taekwondo and Boxing teams in Turkey. Participants were selected by random method. The population of our research is composed of 92 males and 128 females, total of 220 athletes from these teams. The age average of the participants of the study is determined as $24.56 \pm 5.75$.

\subsection{Perceive Social Competence Scale}

In the study, in order to determine the "Perceive Social Competence" levels of the athletes, the scale developed by Anderson-Butcher et al. (2007) and that is adapted to Turkish culture by Sarıçam et al. (2013) is used. The scale consists of 6 items in total. The higher score achieved in the Perceived Social Competence Scale shows the higher social competence. In the scope of this study, the Cronbach Alpha confidence coefficient is determined as 0.89 for the total of the scale.

\subsection{Tendency towards Sports Activities Scale}

In the study, in order to determine the "Tendency towards Sports Activities" the scale developed by Pons et al. (2006) and that is adapted to Turkish by Çevik et al. (2019) is used. The scale is 5 point likert type, consisting of 12 items and 3 factors. 1st factor is named as "Socializing" (Cronbach Alpha 0.75) 2nd factor as "Emotion search" (Cronbach Alpha 0.87), 3rd factor as "Information search" (Cronbach Alpha 0.75). The Cronbach Alpha value for the whole scale is calculated as 0.87 . The socializing factor consists of items 1,2 and 3 , the emotion search factor consists of items $4,5,6,7$ and 8, and the information search factor consists of items 9, 10, 11 and 12 (Çevik et al., 2019).

\subsection{Data Analysis}

The analysis of the gathered data is performed on SPSS 22.0 package program. Whether the data show a normal distribution is analyzed with a Kolmogorov-Smirnov test, and it is seen that they do not present a normal distribution. In group comparison Mann-Whitney U Test, Kruskal-Wallis Test are used. The analysis of the data are assessed at $95 \%$ confidence interval at $\mathrm{p}<0.05$ significance level. 


\section{Results}

Table 1. Demographic information of the participants

\begin{tabular}{|l|l|l|}
\hline Gender & $\mathrm{f}$ & $\%$ \\
\hline Female & 128 & 58.2 \\
\hline Male & 92 & 41.8 \\
\hline Branch & $\mathrm{F}$ & $\%$ \\
\hline Kickboxing & 107 & 49.3 \\
\hline Taekwondo & 58 & 26.4 \\
\hline Boxing & 52 & 23.6 \\
\hline Reason to start the sport & F & $\%$ \\
\hline Through mediation of a friend & 31 & 14.1 \\
\hline Own desire & 130 & 59.1 \\
\hline Will of the family & 29 & 13.2 \\
\hline Direction of my teachers & 14 & 6.4 \\
\hline Other reasons & 16 & 7.3 \\
\hline Are you following the sport news regularly & F & $\%$ \\
\hline Yes & 119 & 54.1 \\
\hline No & 101 & 45.9 \\
\hline
\end{tabular}




\section{Macrothink}

Journal of Educational Issues

ISSN 2377-2263

2021, Vol. 7, No. 2

Table 2. Mann-Whitney $U$ test results of the variation status of the general and sub dimensions of the perceived social competence, sport tendency scale of the participants based on gender variable

\begin{tabular}{|c|c|c|c|c|c|}
\hline Scale & Variable & $\mathrm{n}$ & Mean Ranks & $\mathrm{u}$ & $\mathrm{p}$ \\
\hline \multirow{2}{*}{ Perceived Social Competence } & Female & 125 & 103.37 & \multirow{2}{*}{4975.00} & \multirow{2}{*}{0.049} \\
\hline & Male & 92 & 120.42 & & \\
\hline \multirow{2}{*}{ Sport Tendency Total Score } & Female & 125 & 101.90 & \multirow{2}{*}{4787.50} & \multirow{2}{*}{0.018} \\
\hline & Male & 92 & 122.46 & & \\
\hline \multirow{2}{*}{ Socializing } & Female & 125 & 104.35 & \multirow{2}{*}{5100.50} & \multirow{2}{*}{0.087} \\
\hline & Male & 92 & 119.06 & & \\
\hline \multirow{2}{*}{ Emotion Search } & Female & 125 & 100.26 & \multirow{2}{*}{4577.50} & \multirow{2}{*}{0.004} \\
\hline & Male & 92 & 124.74 & & \\
\hline \multirow{2}{*}{ Information Search } & Female & 125 & 111.46 & \multirow{2}{*}{5765.50} & \multirow{2}{*}{0.791} \\
\hline & Male & 92 & 109.17 & & \\
\hline
\end{tabular}

According to the results of the Mann-Whitney U Test conducted to test whether the variation status of the general and sub dimensions of the perceived social competence, sport tendency scale of the participants based on gender variable is statistically significant, significant differences are detected for the genders of the participants in "Perceived Social Competence" $(\mathrm{U}=4975.00, \mathrm{p}=.049)$, "Sport Tendency Total Score" $(\mathrm{U}=4787.50, \mathrm{p}=.018)$ and "Emotion Search" sub dimension $(\mathrm{U}=4577.50, \mathrm{p}=.004)$. 
Table 3. Kruskal-Wallis test results of variation status of the general and sub dimensions of the perceived social competence, sport tendency scale of the participants based on branch variable

\begin{tabular}{|c|c|c|c|c|c|c|c|}
\hline Scale & Variable & $\mathrm{n}$ & Mean Ranks & $X^{2}$ & sd & $\mathrm{p}$ & $\mathrm{u}$-Test \\
\hline \multirow{3}{*}{ Perceived Social Competence } & Kickboxing & 107 & 122.78 & \multirow{3}{*}{10.71} & \multirow{3}{*}{2} & \multirow{3}{*}{0.005} & \multirow{3}{*}{$\begin{array}{l}1>2 \\
1>3\end{array}$} \\
\hline & Taekwondo & 58 & 99.32 & & & & \\
\hline & Boxing & 52 & 91.44 & & & & \\
\hline \multirow{3}{*}{ Sport Tendency Total } & Kickboxing & 107 & 126.48 & \multirow{3}{*}{17.28} & \multirow{3}{*}{2} & \multirow{3}{*}{0.001} & \multirow{3}{*}{$\begin{array}{l}1>2 \\
1>3\end{array}$} \\
\hline & Taekwondo & 58 & 97.35 & & & & \\
\hline & Boxing & 52 & 86.03 & & & & \\
\hline \multirow{3}{*}{ Socializing } & Kickboxing & 107 & 124.89 & \multirow{3}{*}{18.38} & \multirow{3}{*}{2} & \multirow{3}{*}{0.001} & \multirow{3}{*}{$1>3$} \\
\hline & Taekwondo & 58 & 105.51 & & & & \\
\hline & Boxing & 52 & 80.19 & & & & \\
\hline \multirow{3}{*}{ Emotion Search } & Kickboxing & 107 & 130.29 & \multirow{3}{*}{26.10} & \multirow{3}{*}{2} & \multirow{3}{*}{0.001} & \multirow{3}{*}{$1>3$} \\
\hline & Taekwondo & 58 & 93.87 & & & & \\
\hline & Boxing & 52 & 82.06 & & & & \\
\hline \multirow{3}{*}{ Information Search } & Kickboxing & 107 & 106.42 & \multirow{3}{*}{2.19} & \multirow{3}{*}{2} & \multirow{3}{*}{0.334} & \\
\hline & Taekwondo & 58 & 103.88 & & & & \\
\hline & Boxing & 52 & 120.02 & & & & \\
\hline
\end{tabular}

According to the results of the Kruskal-Wallis Test conducted to test whether the variation status of the general and sub dimensions of the perceived social competence, sport tendency scale of the participants based on branch variable is statistically significant, significant differences are detected in Perceived Social Competence $\left(X^{2}=10.71 \mathrm{sd}=2, \mathrm{p}=.005\right)$, sport tendency general scale $\left(X^{2}=17.28 \mathrm{sd}=2, \mathrm{p}=.001\right)$, Socializing sub dimension $\left(\mathrm{X}^{2}=18.38\right.$ $\mathrm{sd}=2, \mathrm{p}=.001)$ and Emotion Search sub dimension $\left(\mathrm{X}^{2}=26.10 \mathrm{sd}=2, \mathrm{p}=.001\right)$. According to the Mann Whitney U Test conducted to determine from which groups the achieved significant differences result from, the significant difference in Perceived Social Competence scale and sport tendency general score is detected to be between 1st Group and Groups 2 and 3. It is determined that the difference detected in Socializing and Emotion Search sub dimensions is determined to be between Group 1 and Group 3. 
Table 4. Kruskal-Wallis test results of variation status of the general and sub dimensions of the perceived social competence, sport tendency scale of the participants based on reason to start the sport variable

\begin{tabular}{|c|c|c|c|c|c|c|c|}
\hline Scale & Variable & $\mathrm{n}$ & Mean Ranks & $x^{2}$ & $\mathrm{sd}$ & $\mathrm{p}$ & $\mathrm{u}$-Test \\
\hline \multirow{5}{*}{ Perceived Social Competence } & Through my friend's mediation & 31 & 96.87 & \multirow{5}{*}{12.69} & \multirow{5}{*}{4} & \multirow{5}{*}{0.013} & \multirow{5}{*}{$2>3$} \\
\hline & Own desire & 130 & 121.23 & & & & \\
\hline & Will of the family & 29 & 82.81 & & & & \\
\hline & Direction of my teachers & 14 & 88.57 & & & & \\
\hline & Through my friend's mediation & 16 & 119.13 & & & & \\
\hline \multirow{5}{*}{ Sport Tendency Total Score } & Other Reasons & 31 & 96.52 & \multirow{5}{*}{5.48} & \multirow{5}{*}{4} & \multirow{5}{*}{0.241} & \\
\hline & Own desire & 130 & 117.89 & & & & \\
\hline & Will of the family & 29 & 100.34 & & & & \\
\hline & Direction of my teachers & 14 & 90.11 & & & & \\
\hline & Other Reasons & 16 & 113.78 & & & & \\
\hline \multirow{5}{*}{ Socializing } & Through my friend's mediation & 31 & 105.84 & \multirow{5}{*}{3.81} & \multirow{5}{*}{4} & \multirow{5}{*}{0.431} & \\
\hline & Own desire & 130 & 115.63 & & & & \\
\hline & Will of the family & 29 & 93.74 & & & & \\
\hline & Direction of my teachers & 14 & 98.86 & & & & \\
\hline & Other Reasons & 16 & 118.41 & & & & \\
\hline \multirow{5}{*}{ Emotion Search } & Through my friend's mediation & 31 & 94.94 & \multirow{5}{*}{13.65} & \multirow{5}{*}{4} & \multirow{5}{*}{0.008} & \multirow{5}{*}{$2>3$} \\
\hline & Own desire & 130 & 122.09 & & & & \\
\hline & Will of the family & 29 & 88.50 & & & & \\
\hline & Direction of my teachers & 14 & 78.57 & & & & \\
\hline & Other Reasons & 16 & 114.28 & & & & \\
\hline \multirow{5}{*}{ Information Search } & Through my friend's mediation & 31 & 114.76 & \multirow{5}{*}{4.48} & \multirow{5}{*}{4} & \multirow{5}{*}{0.344} & \\
\hline & Own desire & 130 & 105.62 & & & & \\
\hline & Will of the family & 29 & 126.52 & & & & \\
\hline & Direction of my teachers & 14 & 127.89 & & & & \\
\hline & Other Reasons & 16 & 97.63 & & & & \\
\hline
\end{tabular}


According to the results of the Kruskal-Wallis test conducted to test whether the difference is statistically significant according to the reasons to start the sport of the participants, significant differences are detected in Perceived Social Competence $\left(X^{2}=12.69 \mathrm{sd}=4, \mathrm{p}\right.$ $=.013)$ and Emotion Search sub dimension $\left(X^{2}=13.65 \mathrm{sd}=4, \mathrm{p}=.008\right)$ for the participants. According to the Mann Whitney $U$ Test conducted to determine from which groups the achieved significant differences result from, the significant difference in Perceived Social Competence scale and Emotion Search sub dimension is detected to be between groups 2 and 3.

Table 5. Mann-Whitney $U$ test results of variation status of the general and sub dimensions of the perceived social competence, sport tendency scale of the participants based on status of regularly following the sport news variable

\begin{tabular}{|c|c|c|c|c|c|}
\hline Scale & Variable & $\mathrm{n}$ & Mean Ranks & $\mathrm{u}$ & $\mathrm{p}$ \\
\hline \multirow{2}{*}{ Perceived Social Competence } & Yes & 119 & 119.46 & \multirow{2}{*}{4943.00} & \multirow{2}{*}{0.023} \\
\hline & No & 101 & 99.94 & & \\
\hline \multirow{2}{*}{ Sport Tendency Total } & Yes & 119 & 125.75 & \multirow{2}{*}{4194.50} & \multirow{2}{*}{0.001} \\
\hline & No & 101 & 92.53 & & \\
\hline \multirow{2}{*}{ Socializing } & Yes & 119 & 121.47 & \multirow{2}{*}{4704.00} & \multirow{2}{*}{0.005} \\
\hline & No & 101 & 97.57 & & \\
\hline \multirow{2}{*}{ Emotion Search } & Yes & 119 & 122.60 & \multirow{2}{*}{4570.00} & \multirow{2}{*}{0.002} \\
\hline & No & 101 & 96.25 & & \\
\hline \multirow{2}{*}{ Information Search } & Yes & 119 & 121.49 & \multirow{2}{*}{4701.50} & \multirow{2}{*}{0.005} \\
\hline & No & 101 & 97.55 & & \\
\hline
\end{tabular}

According to the results of the Mann-Whitney $U$ test conducted to test whether the difference is statistically significant according to regularly following sport news status of the participants, significant differences are detected in Perceived Social Competence (U = 4943.00, $\mathrm{p}=.023)$, Sport Tendency General $(\mathrm{U}=4194.50, \mathrm{p}=.001)$, Socializing sub dimension $(U=4704.00, p=.005)$, Emotion Search sub dimension $(U=4570.00, p=.002)$ and Information Search sub dimension $(U=4701.50, p=.005)$ perceptions of the participants.

\section{Discussion}

The goal of this study is to assess the perceived social competence and sport activity tendency of the martial artists. The study consists of $58.2 \%$ Female, $41.8 \%$ Male, $49.3 \%$ Kickboxing, 26.4\% Taekwondo and 23.6\% Boxing athletes.

When the perceived social competence levels of the participants in the study is examined 
based on their genders, there is a significant difference found between males and females $(\mathrm{p}<$ 0.05). It is seen that the social competence scores of male athletes are higher than the female athletes. When the Sport Tendency Total Scores of the participants is examined, a significant difference between males and females is detected. It is seen that sport tendency total scores of male athletes are higher compared to female athletes. There is a significant difference in emotion search sub dimension based on gender. Again in this sub dimension, it is seen that the averages of male athletes are higher. Based on gender in Information Search and Socializing sub dimensions no significant difference is found (Table 2). According to the results, it can be said that the social competence perceptions of male athletes is higher compared to the female athletes and tendency towards sport activities is at a higher level in males compared to females. When the literature of the field is reviewed, as the result of the study conducted by Bedard et al. (2020), it is emphasized that for the children at ages of 13-14, the interactions between genders is not significant in participation in sport activities, and sports participation shows similar effects for males and females. Also in the study, they indicate that it is reasonable that the special relation between sports tendency and social competence is same for male and female children. Kara et al. (2018), as the result of their study, detected that there is no significant difference between the perceived social competence scores based on gender. When different studies are reviewed, there are result as both females having higher level of social competence perception than males (Coleman, 2003) and males having higher level social competence perception than females (Torres et al., 2003; Koparan et al., 2009). In many research in the past, especially due to roles and responsibilities forced on to females, it is noted that females are distanced from matters like social environments and education (Sancar, 2013).

When the results achieved according to the branches of the participants of the study, significant differences are found in social competence, sport tendency total score, socializing and emotion search sub dimensions $(\mathrm{p}<0.05)$. When the significant differences are examined, it is seen that the averages of kickboxing athletes are higher than that of Taekwondo and boxing branches. Between the branches no significant difference is seen in Information Search sub dimension $(\mathrm{p}>0.05)$ (Table 3$)$. When the literature of the field is reviewed, as the result of the study conducted by Bedard et al. (2020), it is emphasized that for the children at ages of 13-14, a significant relation is found in sport activity tendency of sport participants and non-participants. Donaldson and Ronan (2006) found out that in a population of young teenagers, the sports participation has positive relationship with many aspects of concept of self, including the perceived social competences in addition to athletic qualification and self-value perception. Linver et al. (2009) found out that compared to not participating in any organized activity, the participation in sports and other organized activities is related to highest level positive academic and social competence, confidence and positive social behavior. Viau et al. (2015), while examining the effect of participation in organized activities (sports, cultural and prosocial activities) on various indicators of 18 years old teenager adaptation like depression indicators, problematic alcohol consumption and civil participation, reached similar positive results. When the literature is reviewed and the results from this study are evaluated, similar findings are seen. A continuous tendency towards sports or other activities can be said to affect positively the social competences of people. 
When we examined based on the reasons to start the sport of the athletes, significant differences are found in Perceived Social Competence and sport activity tendency sub dimension Emotion Search $(\mathrm{p}<0.05)$. It is seen that the athletes who started on their own desire has higher average than athletes started the sport under the will of the family. In Sport Tendency Total Score, Socializing and Information Search sub dimensions there are no significant differences $(\mathrm{p}>0.05)$ (Table 4$)$. When the results are evaluated, it can be said that fighting athletes who started the sport on their own desire have higher averages in perceived social competences and sport activity tendencies. The competences of the ones who start the sport on their own desire being higher compared to other directions can be due to the athletes engaging in the sports branch on their own desire instead of different directions. This results suggests us that it is important to ask the opinion of the athletes to start sports in advance and them to start in sport branches in line with their wishes in development in those branches regarding social competence. In this way, socially successful athletes can be trained. When the field literature is reviewed, in the study conducted by Bedard et al. (2020), it is emphasized that in the tendency of the teenagers towards sport activities, the family, coaches, peer groups and various ecological systems have a strong bond in the tendency to sports or any physical activity, also the peer groups may encourage another person to participate in a sport activity; when the person joins the team, they feel valuable for and bonded to the team and their peers. As conforming to the socially approved norm, this positive interaction with peers is claimed to facilitate the development of perceived social competence and general concept of self.

According to the status of the athletes participated in the study regarding them following regularly the sport news, in Perceived Social Competence, sport activity tendency total score, Socializing, Emotion Search and Information Search sub dimensions, significant differences are detected $(\mathrm{p}<0.05)$. It is seen that the social competence and sport tendencies of the athletes who follow the sport news regularly are higher (Table 5). By this result, following the up-to-date sport news can be said to increase the social competence and sport tendencies of the athletes. Athletes following the current sport news special to their own or other branches is thought provide benefit for them to stay in the sport and follow the changing rules and technical-tactical developments.

As a conclusion, it is found out that they follow the current sports, and this increases the social competence and sport tendencies of the athletes, the social competencies and sport tendencies of the kickboxing athletes, one who started to the sport on their own desire and male athletes are higher. As the result of this study, it can be recommended that similar studies can be conducted with athletes of other fighting sports or with more participants in different branches.

\section{References}

Ak, A. (2017). Türk Sporunda Sorunlar ve Çözüm Önerileri. Ankara: Spor Yayınevi ve Kitabevi.

Anderson-Butcher, D., Iachini, A. L., \& Amorose, A. J. (2007). Initial reliability and validity of perceived social competence scale. Research on Social Work Practice, 18(1), 47-54. 
https://doi.org/10.1177/1049731507304364

Balyan, M. (2012). Türkiye akademi liginde yer alan futbolcuların (U14 ve U15) spora yönelimleri ve sosyal beceri düzeyleri arasındaki ilişki. Uluslararası Hakemli Beşeri ve Akademik Bilimler Dergisi, 1(1), 142-151. https://doi.org/10.17368/UHBAB.2012018732

Başer, E. (1996). Futbolda Psikoloji ve Başarı Sporsal Kuram Dizisi 4. Ankara: Bağırgan Yayımevi.

Bedard, C., Hanna, S., \& Cairney, J. (2020). A longitudinal study of sport participation and perceived social competence in youth. Journal of Adolescent Health, 66(3), 352-359. https://doi.org/10.1016/j.jadohealth.2019.09.017

Cervelló, E. M., Escarti, A., \& Guzman, J. F. (2007). Youth sport dropout from the achievement goal theory. Psicothema, 19(1), 65-71.

Ceylan, T., Ermiş, E., Ceylan, L., \& Erilli, N. A. (2020). Futbol hakemlerinin sargınlık ve öz yeterlik düzeylerinin incelenmesi. Journal of International Social Research, 13(75), 934-940. https://doi.org/10.17719/jisr.11161

Donaldson, S. J., \& Ronan, K. R. (2006). The effects of sports participation on young adolescents' emotional well-being. Adolescence, 41(162), 369-389.

Eniseler, N. (2009). Çocuk ve Futbol Antrenmanı. İstanbul: TFF Yayınları.

Ministry of Development. (2013). Beş yıllık kalkınma planı spor ÖIK raporu. Ankara, Turkey.

Kara, F. M., Gürbüz, B., \& Sarol, H. (2018). An investigation of adult's leisure boredom, percieved social competence and self-esteem. International Journal of Sport, Exercise \& Training Sciences, 4(4), 113-121. https://doi.org/10.18826/useeabd.473994

King, B. (2004). What makes fans tick? Sports Business Journal, 7, 25-34.

Linver, M. R., Roth, J. L., \& Brooks-Gunn, J. (2009). Patterns of adolescents' participation in organized activities: Are sports best when combined with other activities? Developmental Psychology, 45(2), 354. https://doi.org/10.1037/a0014133

Ntoumanis, N. (2001). Empirical links between achievement goal theory and self-determination theory in sport. Journal of Sports Sciences, 19(6), 397-409. https://doi.org/ $10.1080 / 026404101300149357$

Othig, P. (2002). Grössing S. Sport und Gesellschaft. Limpert Verlag Wiebelsheim: Limpert.

Pons, F., Mourali, M., \& Nyeck, S. (2006). Consumer orientation toward sporting events: Scale development and validation. Journal of Service Research, 8(3), 276-287. https://doi.org/10.1177/1094670505283931

Rottensteiner, C., Tolvanen, A., Laakso, L., \& Konttinen, N. (2015). Youth athletes' motivation, perceived competence, and persistence in organized team sports. Journal of Sport Behavior, 38(4), 1-18. 


\section{Macrothink}

Sarıçam, H., Akın, A., Akın, Ü., \& Çardak, M. (2013). Algilanan sosyal yetkinlik ölçeğinin türkçeye uyarlanması: Geçerlik ve güvenirlik çalışması. The Journal of Academic Social Science Studies, 6(3), 591-600.

Sunay, H. (2019). Türkiye Almanya ABD ve Avustralya spor sistemlerinin bazı değişkenler açısından karşılaştırılması OPUS Uluslararası Toplum Araştırmaları Dergisi, 14(20), 488-513. https://doi.org/10.26466/opus.585855

Viau, A., Denault, A. S., \& Poulin, F. (2015). Organized activities during high school and adjustment one year post high school: Identifying social mediators. Journal of Youth and Adolescence, 44, 1638-1651. https://doi.org/10.1007/s10964-014-0225-5

\section{Copyright Disclaimer}

Copyright for this article is retained by the author(s), with first publication rights granted to the journal.

This is an open-access article distributed under the terms and conditions of the Creative Commons Attribution license (http://creativecommons.org/licenses/by/3.0/). 